\title{
Assessing the Degradation Ability and Nutritional Quality of Different Strains of Milky Mushroom
}

\author{
P. Venkatesh", N. Revathy and N. Kavi Bharathi
}

Department of Plant Pathology, Agricultural College and Research Institute, Madurai, India

*Corresponding author

\begin{abstract}
A B S T R A C T
\section{Keywords}

Degradation ability, Nutritional quality, Milky mushroom, Carbohydrates, Digestible crude protein

Article Info

Accepted:

22 July 2019

Available Online:

10 August 2019
\end{abstract}

\section{Introduction}

Milky mushrooms are with great source quality protein, minerals and various vitamins. From the age old period of time mushroom were used as a food materials without knowing its medicinal values. It is an important food item concerning human health, nutrition and disease prevention. Gruen and Wong (1982) indicated that edible mushrooms were highly nutritional and compared favourably with meat, egg and milk food sources. Different strains of Calocybe indica ability to adopt wide range of the temperature, $\mathrm{pH}$ levels and yield potential depending on the substrates used. It is more attractive with excellent shelf-life, grows on several agricultural wastes and on wide range of temperatures (Singh et al., 2015). C. indica has great demand in many parts of the country due to its attractive milky white sporocarp, typical wild mushroom taste, fibrous feel of the texture, long shelf. This mushroom was first collected in wild form from West Bengal (India) by Purkayastha and Chandra in 1974. Production technology of Calocybe indica has been introduced by Purkayastha and Nayak in 1979 which was improved by Purkayastha and Nayak in 1981.Milky mushroom cultivation has proved its economic strength 
and ecological importance for efficient utilization, value-addition and biotransformation of agro-industrial residues (Zervakis and Philippoussis 2000). Commercial mushroom production is yet another efficient and relatively short biological process of food protein recovery from unutilized lignocellulosic materials through enzymatic degrading capabilities of mushroom fungi (Chiu and Moore, 2001).

\section{Materials and Methods}

\section{Estimation of enzymes}

\section{Endoglucanase}

Celluloytic enzymes namely, Endo- $\beta$-D-1, 4glucanase activity was measured by estimation of the reducing sugars released during incubation of the substrate with enzyme extract according to method Mandels et al. (1976). The reducing sugars were estimated using DNS reagent (Miller, 1959).

\section{Reagents}

1) $0.1 \mathrm{M}$ citrate buffer ( $\mathrm{pH} 4.8$ )

A. $0.1 \mathrm{M}$ Citric acid

B. $0.1 \mathrm{M}$ tri sodium citrate

$23 \mathrm{ml}$ of A and $27 \mathrm{ml}$ of $\mathrm{B}$ and volume made upto $100 \mathrm{ml}$ with distilled water.

2) Carboxy Methyl Cellulose solution (CMC) $1 \mathrm{~g}$ of Cellulose solution was dissolved in 90 $\mathrm{ml}$ of $0.1 \mathrm{M}$ citrate buffer of $\mathrm{pH} 4.8$ and volume was made to $100 \mathrm{ml}$.

3) Dinitrosalicylic acid (DNS) solution

$10 \mathrm{~g}$ of DNS and $0.5 \mathrm{~g}$ sodium sulfite in 500 $\mathrm{ml}$ of $2 \% \mathrm{NaOH}$ solution already prepared in distilled water were added. The solution was allowed to cool, $2 \mathrm{~g}$ of phenol was dissolved in it and final volume was made to $1000 \mathrm{ml}$.
The solution was filtered and stored in dark bottles in refrigerator.

4) Sodium potassium tartarate solution (40\%) (Rochelle salt)

$40 \mathrm{~g}$ of sodium potassium tartarate was dissolved in $100 \mathrm{ml}$ distilled water. The solution was filtered and stored at room temperature.

\section{Assay}

The test tubes containing a mixture of $0.5 \mathrm{ml}$ CMC solution and $0.5 \mathrm{ml}$ of appropriately diluted enzyme extract were incubated at $50^{\circ} \mathrm{C}$ for 30 minutes in water bath. Controls devoid of enzyme extract were also run simultaneously. Reducing sugars produced during this reaction were measured by using DNS method. $3 \mathrm{ml}$ of DNS was added to each tube and kept in boiling water bath for 15 mins. While still hot, $1 \mathrm{ml}$ of sodium potassium tartarate solution was added, the contents were cooled to room temperature followed by addition of $2 \mathrm{ml}$ of distilled water in each test tube. The percent light absorbance by the resulting solution was recorded at 575 $\mathrm{nm}$ in a spectronic 20. The corresponding enzyme activity was calculated from the standard curve.

\section{Exoglucanase}

Cellobiohydrolase activity was determined by the method reported by Mandels and sternberg (1976).

\section{Reagents}

1) $0.1 \mathrm{M}$ citrate buffer ( $\mathrm{pH} 4.8$ )

2) DNS solution

3) Sodium potassium tartarate solution (40\%)

4) Filter paper strips (Whatmann no.1, 1x 6 $\mathrm{cm})$ 


\section{Assay}

The test tube containing $0.5 \mathrm{ml}$ enzyme extract and $1 \mathrm{ml}$ of citrate buffer and a filter paper strip were incubated at $50^{\circ} \mathrm{C}$ for 1 hour in water bath. Controls were run simultaneously. The reducing sugars produced during the reaction were estimated by DNS method as described in section 3.16.1.

\section{Preparation of standard curve}

A standard curve for measurement of reducing sugars was prepared under the same conditions Miller (1959), as described above using standard solution of glucose from 0.1 $0.5 \mathrm{mg} / \mathrm{ml}$ concentration.

\section{Enzyme units}

Enzyme activity of endoglucanase and exoglucanase was expressed as $\mu$ moles glucose $/ \mathrm{min} / \mathrm{ml}$ of culture filtrate or $/ \mathrm{g}$ straw. Specific activity was expressed as $\mu$ moles glucose $/ \mathrm{min} / \mathrm{mg}$ protein.

\section{Endoxylanase}

Xylanase (hemicellulase) activity was assayed according to the method of Erikson andBucht (1968)

\section{Reagents}

1) Xylan solution

$1 \mathrm{gm}$ of xylan was dissolved in $0.05 \mathrm{M}$ citrate buffer, pH 4.8 and volume made to $100 \mathrm{ml}$.

2) DNS reagent

3) Sodium potassium tartarate solution (40\%)

\section{Procedure}

$1 \mathrm{ml}$ of sample of approximately diluted culture was mixed with $1 \mathrm{ml}$ of $1 \%$ xylan solution and incubated for 30 minutes at $50^{\circ} \mathrm{C}$.
Reducing sugars were measured as xylose equivalents by DNS method as described in 3.16.1.

\section{Units of enzyme activity}

One unit of enzyme activity is expressed as amount of xylanase catalyzed the formation of $1 \mu \mathrm{mol} x y l o s e / \mathrm{min} / \mathrm{ml}$ of culture filtrate or /g straw. Specific activity was expressed as $\mu \mathrm{mol} x y l o s e / \mathrm{min} / \mathrm{mg}$ protein.

\section{Nutritive value of different strains of milky mushroom}

The various constituents in the sporophores of different strains of milky mushroom(CI-1, CI2, CI-3, CI-5and var. APK-2) were analyzed on dry weight basis by the following methods.

\section{Determination of moisture content}

The moisture content of the sporophore was estimated by drying $25 \mathrm{~g}$ of fresh sporophore in an oven at $80^{\circ} \mathrm{C}$ for three consecutive days. It was cooled in a desiccator and weighed. The moisture content was calculated as,

Fresh weight - Dry weight

Moisture content $(\%)=$--------------- $\times 100$

Fresh weight

\section{Determination of total carbohydrates}

The anthrone method described by Hedge et al. (1962) was followed to determine the total carbohydrates.

One hundred $\mathrm{mg}$ of the sample was hydrolysed in a boiling tube by keeping it in a boiling water bath for three hrs with five $\mathrm{ml}$ of $2.5 \mathrm{~N} \mathrm{HC1}$ and cooled to room temperature. This was neutralised with solid sodium carbonate until the effervescence ceased. Solution was centrifuged after making the volume upto $100 \mathrm{ml}$. From the 
supernatant, 0.5 and $1 \mathrm{ml}$ of aliquots were drawn for analysis. Volume was made up to one $\mathrm{ml}$ using distilled water and added four $\mathrm{ml}$ of anthrone reagent. Heated for $8 \mathrm{mins}$ in a boiling water bath and rapidly cooled. Green colour obtained was read at $630 \mathrm{~nm}$ by using Spectronic-20. Amount of total carbohydrates present was calculated from the standard graph.

\section{Determination of crude protein}

The total nitrogen content was estimated by the Micro-kjeldahl method.

One $\mathrm{g}$ of powdered sample was taken in a digestion tube to this $0.05 \mathrm{~g}$ of digestion mixture (selenium dioxide, copper sulphate, potassium sulphate (1: 8: 40), ground separately and mixed well) was added followed by $10 \mathrm{ml}$ of conc. sulphuric acid.

The mixture was digested till it turned to colourless solution. The digest was then cooled and the volume was made upto $100 \mathrm{ml}$ with distilled water. $10 \mathrm{ml}$ of aliquot was taken, distilled and titrated against $0.1 \mathrm{~N} \mathrm{HC1}$ by using Micro Kjeltech unit (Vapodest, version 45).

A reagent blank with an equal volume of distilled water was run and the titration value was subtracted from the sample titrate value.

Nitrogen content estimated as $\mathrm{N}$ in $\mathrm{g} \mathrm{kg}^{-1}=$

(ml HCL - ml blank) Normality $\times 14.01$

$$
\text { Weight (g) }
$$

The digestible crude protein content was obtained by multiplying the total nitrogen value with the factor 4. 38 (Crisan and Sands, 1978).

\section{Determination of crude fat}

The crude fat in the sporophores was estimated by Soxhlet method (Lees, 1975). In the pre-weighed extraction flask, two $g$ of the dried sporophore was kept in the extraction thimble. The thimble was placed in the extractor for the extraction of crude fat using $100 \mathrm{ml}$ of petroleum ether (b. p. $49-60^{\circ} \mathrm{C}$ ) by heating over a water bath. After six to eight siphoning, the petroleum ether was evaporated in a water bath. The fat content was recorded after cooling in a desiccator. Percentage of crude fat was calculated as,

(Weight of flask + ether extract) - Weight of flask Sample weight

\section{Determination of crude fiber}

The crude fiber content in the sporophore was estimated following the method of De (1965). The residue in the thimble, after extracting crude fat was transferred to a beaker and boiled for $30 \mathrm{mins}$ with $200 \mathrm{ml}$ of 1.25 per cent sulphuric acid.

The mixture was filtered through a muslin cloth and the residue was washed for free of acid with water. The residue was transferred to a beaker containing $200 \mathrm{ml}$ of 1.25 per cent sodium hydroxide and boiled for 30 mins. The solution was filtered through muslin cloth and washed with $25 \mathrm{ml}$ of boiling 1.25 per cent sulphuric acid, $350 \mathrm{ml}$ portions of water and $25 \mathrm{ml}$ alcohol. Residue was transferred to silica dish and dried fortwo hrs at $130 \pm 2^{\circ} \mathrm{C}$. Dish was cooled in a desiccator, weighed and ignited at $600+15^{\circ} \mathrm{C}$ for 30 mins, cooled and weighed.

Per cent crude fiber content $=$

Loss in weight on ignition $\times 100$

Weight of the sample 


\section{Determination of ash content}

A quantity of five $g$ of dried and powdered sporophore was ignited in a silica dish for five $\mathrm{h}$ at $6000^{\circ} \mathrm{C}$ till a white ash was obtained, cooled and weighed (Raghuramulu et al., 1983).

\section{Determination of energy value}

The energy value of oyster mushroom species was estimated based on the content of crude protein, crude fat and total carbohydrates in the mushroom using the factor 2.62,8.37 and $4.2 \mathrm{k}$ cal per gram of each component respectively(Crisan et al., 1978).

Energy value $(\mathrm{k} \mathrm{cal} / 100 \mathrm{~g}$ dry weight $)=2.62$ $(\% \mathrm{~N} \times 6.25)+8.37$ (\% fat $)+4.2$ (\% total carbohydrates)

\section{Results and Discussion}

\section{Enzyme activity}

Production of enzyme is of prime importance for efficient degradation of substrates and utilization of nutrients. The enzymes such as cellulase and laccase are responsible for degradation of cellulose and lignin content present in the substrates. The efficiency of the enzyme production positively correlates with the yield of mushroom.
Among the five strains tested, CI-3 recorded maximum activity of endoglucanase, exoglucanase, and endoxylanese (1.50, 1.02, $1.66 \mu \mathrm{moles}$ sugar $/ \mathrm{min} / \mathrm{mg}$ protein,) followed by strain APK-2 (1.22, 0.23and $0.72 \mu$ moles sugar/min/mg protein). The least level of endoglucanase activity recorded in both the strains CI -2 and CI -5 (0.20 and $0.17 \mu$ moles sugar/min/mg protein). Minimum level of exoglucanase activity was measured in strain CI-5 (0.06 $\mu$ moles sugar/min/mg protein). CI1 and CI-5 recorded the low level of endoxylanase activity $(0.51$ and 0.54 . $\mu$ moles sugar/min/mg protein) which correlates withRamkumar et al. (2011) revealed that $\mathrm{CaCO}_{3}$ (2percent) amended Czapeck's Dox liquid medium recorded the high level of lignocellulolytic enzyme production viz., exo$\beta-1,4$ glucanase 2.31 and endo $\beta-1,4$ glucanase $1.59, \beta$ glucosidase (1.79), xylanase ( 1.94$)$, laccase polyphenol oxidase $(0.82)$ in Lentinuseddodes. (1.85) and

Bhupathi et al. (2017)recorded maximum level of xylanase at all the seven stages of mushroom growth followed by lipoxygenase activity. Maximum activity of xylanase was recorded in the pileus of APK-2. variety and CBE-TNAU-1523 wild strain (3.514 $\mathrm{mols} / \mathrm{min} / \mathrm{g}$ and 3.55 moles/ $\mathrm{min} / \mathrm{g}$ respectively) when compare to stipe(Table 1).

Table.1 In vitro activity of endoglucanase, exoglucanase and xylanase production of different strains of milky mushroom

\begin{tabular}{|l|l|c|c|c|}
\hline \multirow{2}{*}{ S.No. } & \multirow{2}{*}{ Strains } & \multicolumn{2}{|c|}{ Cellulase $(\boldsymbol{\mu m o l e s}$ glucose $/ \mathbf{m l})$} & Xylanase \\
\cline { 3 - 5 } & & Endoglucanase & Exoglucanase & Endoxylanase(1 $\boldsymbol{\mu m o l}$ xylose/ml) \\
\hline 1. & C.indica- CI-1 & 1.09 & 0.19 & 0.72 \\
\hline 2. & C. indica- CI -2 & 0.20 & 0.14 & 0.51 \\
\hline 3. & C. indica-CI-3 & 1.50 & 1.02 & 1.66 \\
\hline 4. & C. indica- CI-5 & 0.17 & 0.06 & 0.54 \\
\hline 5. & C. indica -APK-2 & 1.22 & 0.23 & 0.82 \\
\hline & CD $(\mathbf{P = 0 . 0 5 )}$ & $\mathbf{0 . 0 5}$ & $\mathbf{0 . 0 1}$ & $\mathbf{0 . 0 4}$ \\
\hline
\end{tabular}


Table.2 Proximate composition of milky mushroom (percent dry weight basis)

\begin{tabular}{|c|l|c|c|c|c|c|c|l|}
\hline S.No & $\begin{array}{l}\text { Strains of milky } \\
\text { mushroom }\end{array}$ & $\begin{array}{c}\text { Moisture } \\
\text { content }\end{array}$ & $\begin{array}{c}\text { TotalCarbohy } \\
\text { drate }\end{array}$ & $\begin{array}{c}\text { Crude } \\
\text { protein }\end{array}$ & $\begin{array}{c}\text { Crude } \\
\text { fat }\end{array}$ & $\begin{array}{c}\text { Crude } \\
\text { fiber }\end{array}$ & Ash & $\begin{array}{c}\text { CalorieVal } \\
\text { ue (k/100g) }\end{array}$ \\
\hline 1. & C. indica-CI-1 & 86.7 & 55.32 & 18.20 & 3.82 & 8.65 & 9.2 & 328.46 \\
\hline $\mathbf{2 .}$ & C. indica-CI - & 88.9 & 50.12 & 19.39 & 4.01 & 7.91 & 8.38 & 310.26 \\
\hline 3. & C. indica-CI-3 & 86.4 & 42.32 & 24.50 & 3.58 & 9.84 & 8.64 & 229.5 \\
\hline $\mathbf{4 .}$ & C. indica-CI-5 & 88.0 & 48.50 & 19.85 & 4.74 & 9.32 & 9.86 & 305.98 \\
\hline $\mathbf{5 .}$ & $\begin{array}{l}\text { C. } \text { indica-var. } \\
\text { APK-2 }\end{array}$ & 87.5 & 47.08 & 20.2 & 3.62 & 8.54 & 9.52 & 301.7 \\
\hline & CD(P=0.05) & $\mathbf{4 . 1}$ & $\mathbf{1 . 8 3}$ & $\mathbf{1 . 0 8}$ & $\mathbf{0 . 1 7}$ & $\mathbf{0 . 3 2}$ & $\mathbf{0 . 5 0}$ & \\
\hline
\end{tabular}

\section{Proximate composition of milky mushroom}

Mushrooms are considered as a one of world's greatest untapped resources of nutritious and palatable food (Subramanian $e t$ al. (2015). Pani et al. (2012) revealed that milky mushroom are rich in various nutrient source like protein, fiber, mineral, carbohydrate and more amount of essential amino acids.

The results registered that different strains of milky mushroom were found to contain 86.42 to 88.9 per cent moisture, 42.32 to 55.32 per cent total carbohydrates, 18.20 to 24.50 per cent digestible crude protein, 3.58 to 4.74 per cent crude fat, 7.91 to 9.84 per cent crude fiber and 8.38 to 9.86 per cent ash content on dry weight basis. They possessed an energy value of 229.5 to $311.34 \mathrm{k} \mathrm{cal} / 100 \mathrm{~g}$. Alamet al. (2008) suggested that the $100 \mathrm{~g}$ of dried mushroom consists $24 \mathrm{~g}$ of protein, $4.5 \mathrm{~g}$ of lipid, $12.9 \mathrm{~g}$ of fiber, $13.1 \mathrm{~g}$ of ash, $48.5 \%$ of carbohydrate and $87 \%$ of moisture level. Doshiet al. (1988) reported that mature sporophore of Calocybeindicahad soluble sugars $(4 \%)$, starch $(2.9 \%)$ and ash $(7.4 \%)$ Dhakad et al. (2017) conducted an experiment on five different strains of milky mushroom to estimate the nutrient status and founded that highest level $(0.14 \mathrm{mg} / \mathrm{g}$ of fresh mushroom) of protein content in the strain CI-8,other strain CI-15,CI-13 and CI-14 had the protein content of $0.12 \mathrm{mg} / \mathrm{g}, 0.09 \mathrm{mg} / \mathrm{g}$ and 0.06 $\mathrm{mg} / \mathrm{g}$ respectively (Table 2 ).

\section{References}

Alam, N., Amin, R., Khan, A., Ara, I., Shim, M. J., Lee, M. W., \& Lee, T. S. (2008). Nutritional analysis of cultivated mushrooms in Bangladesh-Pleurotus ostreatus. Pleurotus sajor-caju, Pleurotus florida and Calocybe indica. Mycobiology. 36(4), 228-232.

Bhupathi, P., Krishnamoorthy, A. S., \& Uthandi, S. (2017). Profiling of morphogenesis related enzymes of milky mushroom Calocybe indica (P \& C). Journal of Pharmacognosy and Phytochemistr. 6(5), 2537-2543

Crisan, E., \& Sands, A. (1978). Nutritional value: Academic Press, New York.

Chiu SW, Moore DA.(2001). Threats to biodiversity caused by traditional mushroom cultivation technology in China. In British Mycological Society Symposium Series. 22:111-119.

De, S. K. (1965). Practical Agricultural Chemistry: Narayanan Publishing Home, Allahabad, India.

Doshi A, Sharma S (1988). Wild mushrooms of Rajasthan. In: Rai RD, Dhar BL, Verm RN (eds). Advances in Mushroom Biology and Production. Mushroom Society of India, National 
Research Centre for Mushroom, Solan, Chambaghat (HP), India. pp. 105-127.

Dhakad, P., Chandra, R., Yadav, M., \& Patar, U. R. (2017). Comparative Study on Nutraceuticals of Five Strains of Milky Mushroom (Calocybe indica). Int. J. Curr. Microbiol. App. Sci, 6(2). 645648.

Gruen VEC, Wong HX (1982). Immunodulatory and Antitumour mushrooms" Inter J. Pharm. Biol., 42: 179-185.

Hedge, J., Hofreiter, B., \& Whistler, R. (1962). Carbohydrate chemistry. Academic Press, New York, 17.

Lees, R. (1975). Food analysis: analytical and quality control methods for the food manufacturer and buyer: Leonard Hill Books.

Miller, G. L. (1959). Use of dinitrosalicylic acid reagent for determination of reducing sugar. Analytical chemistry. 31(3), 426-428.

Mandels, M., Andreotti, R., \& Roche, C. (1976). Measurement of saccharifying cellulase. Paper presented at the Biotechnol. Bioeng. Symp,United States.

Pani, B. M., Mullarkey, E. E., Aronowicz, J., Assimacopoulos, S., Grove, E. A., \& Lowe, C. J. (2012). Ancient deuterostome origins of vertebrate brain signalling centres. Nature, 483(7389), 289.

Raghuramulu, N., Nair, M., \& Kalyansundaram, S. (1983). A manual of laboratory techniques, National Institute of Nutrition, ICMR. Hyderabad, India: Jamia Osmania. P, 178-179.

Ramkumar, L., Ramanathan, T., \& Nedumaran, T. (2011). In vitro effect of organic and inorganic additives from the production of radial mycelial growth and lignocellulolytic enzyme in Lentinus edodes (Berk.) Sing. Emirates Journal of Food and Agriculture, 23(1), 71.

Subramanian, K., \& Shanmugasundaram, K. (2015). Optimization of casing process for enhanced bioefficiency of Calocybe indica, an indigenous tropical edible mushroom. International Journal of Recent Scientific Research, 6(2), 25942598.

Zervakis G, Philippoussis A. Management of agro-industrial wastes through the cultivation of edible mushrooms. In Proceedings of IV European Waste Forum 'Innovation in waste management', CIPA, Milan, 2000.

\section{How to cite this article:}

Venkatesh, P., N. Revathy and Kavi Bharathi, N. 2019. Assessing the Degradation Ability and Nutritional Quality of Different Strains of Milky Mushroom. Int.J.Curr.Microbiol.App.Sci. 8(08): 2972-2978. doi: https://doi.org/10.20546/ijcmas.2019.808.343 